\title{
Exploring the Intersection of Culture and Education in Nunavik
}

Nicole Ives, MSW, PhD

McGill University School of Social Work

Assistant Professor, McGill University, School of Social Work

3506 University Street, \#309, Montreal, QC H3A 2A7

nicole.ives@mcgill.ca

Vandna Sinha, PhD

McGill University School of Social Work

Dominique Leman, MSW

Anna Goren, BA

Robert Levy-Powell, PhD

Kativik School Board

Wendy Thomson, PhD

McGill University School of Social Work 
Abstract: During the last century, Nunavik's Inuit population has experienced social transformations which have manifested themselves in a range of social issues. Nunavik lies north of the $55^{\text {th }}$ parallel in Quebec, Canada and is one of four regions in Canada that comprise Inuit Nunaat (Inuvialuit, Nunatsiavut, Nunavik, and Nunavut) - Inuit homeland. The Inuit are one of three distinct Indigenous groups in Canada as defined by the Constitution Act, 1982, with distinct cultural heritage and language. Community Capability and Development in Nunavik, a collaborative project between McGill School of Social Work researchers and an Advisory Committee composed of representatives from key Inuit institutions, explored social issues and community assets in Nunavik. This study sought to (a) provide a forum for community members to voice issues important to them; (b) inform policy development prior to the vote on regional government; and (c) increase the growth of community linkages that support research dissemination via a network of researchers, community members and organizations.

This qualitative project involved 52 semi-structured, face-to-face interviews with members of five Nunavik communities. Salient themes focused on bridging generational gaps in culture, education, and language given the rapidly growing youth population, and the challenges of competing frameworks (Inuit vs. Qallunaat [non-Inuit]) of competent social work practice. This paper draws on data from this larger study of Nunavimmiut (residents of Nunavik) understandings of social programs, community strengths and social policies to examine how the intersection of education and culture in Nunavik can inform community capacity to identify challenges and activate solutions, in this case, addressing low academic retention.

\section{Exploring the Intersection of Culture and Education in Nunavik}

\section{Introduction}

The Inuit are one of three distinct Indigenous groups in Canada as defined by the Constitution Act, 1982, with distinct cultural heritage and language. Nunavik (population 9,565 Inuit) lies north of the $55^{\text {th }}$ parallel in Quebec and is one of four regions in Canada that comprise Inuit Nunaat (Inuvialuit, Nunatsiavut, Nunavik, and Nunavut) - Inuit homeland. The Inuit population of Nunavik has experienced social upheaval and transformation during the last century. Their social system has shifted from one grounded in informal networks of extended family and community to one in which there has been increasing presence of Southern (nonInuit) government and in which Indigenous understandings of family, education, justice and community compete with interpretations imported from Quebec (Chabot, 2003).

Inuit communities in Nunavik experience some of the most serious social problems in Canada, with communities suffering from high rates of substance abuse, overcrowded housing and widespread poverty (Archibald \& Grey, 2000; Vick-Westgate, 2002). Educational statistics from the 2006 census reveal Nunavik's need to increase its educational capacity. Approximately $50 \%$ of the Inuit population does not complete high school (Statistics Canada, 2006). Social programs and services delivered in Nunavik represent a significant public expenditure, and an important component of Quebec's strategy to reduce social exclusion. Despite this investment, however, the people of Nunavik continue to experience poor health and social outcomes relative to non-Indigenous Canadians.

This paper draws on data from a larger study of Nunavimmiut (residents of Nunavik) understandings of social programs, community strengths and social policies to examine how the intersection of education and culture in Nunavik can inform community capacity to identify challenges and activate solutions, in this case, addressing low academic retention.

\section{Background}

Traditionally, the Inuit of Nunavik were a semi-nomadic people with a subsistence-based economy. A communal structure in which dwellings housed extended families living together allowed for a parenting style characterized by high degrees of independence and permissive- 
ness by Southern standards, accompanied by significant nurturing and affection for children who were viewed as the center of community life (McShane, 2009). Education was not separated from day-to-day living; knowledge transmission in Inuit culture was based on shared experiences which allowed elders and parents to show young Inuit what they needed to know in terms of life-skills (Penny, 2009; Vick-Westgate, 2002). At the same time, Inuit youth would also learn about traditional Inuit culture, values and traditions. The Inuit communal ethos was woven into all aspects of daily life: hunters provided for the community, dwellings were commonly shared with extended family members, and elders provided counseling and healing to those whom they identified as needing it, rather than waiting for the troubled or sick to seek help as is typical in the modern social services system (Pauktuutit, 2006). This way of life nurtured a culture centered around community, land-based activity, and a spiritual connection to nature.

The 1940s and 1950s brought the end of the fur trade, which had been responsible for the developments of settlements in the region starting in the 1800 s. This socioeconomic shift left the region of Nunavik economically and socially dependent on the outside world, and was marked by considerable trauma. When governments stepped in to provide assistance, Nunavimmiut settled into villages to better access these services, such as formal schools, hospitals, and centres locaux de services communautaires (local community service centres; CLSCs). However, as a consequence, their semi-nomadic lifestyle and subsistencebased economy were no longer viable. As a result, most Inuit were forced to depend on government for their survival (Duhaime, 2007). Over time, permanent settlements also separated Inuit from their traditional means of subsistence, eroding a sense of traditional land-based culture and group belongingness, while imposing a new definition of community and familial roles (McShane, 2009).

The late 1970s brought key changes in Nunavik's structural history. In 1975, the signing of the James Bay and Northern Quebec Agreement marked a paradigm shift, bringing an official land claims settlement and the establishment of formal bodies to head different areas of social and political life. This agreement marked a significant event in the long struggle for Inuit autonomy. In addition to providing a monetary settlement, it created a new structure for regional administrative governance (Rodon \& Grey, 2009; Wilson, 2008), providing Nunavimmiut some measure of control through their operation of three independent regional administrative bodies - the Kativik Regional Government (KRG), the Kativik School Board (KSB), and the Nunavik Regional Board of Health and Social Services (NRBHSS). The Kativik School Board was the first Inuit-controlled school district established in Canada, and was given the powers and responsibilities to provide education in Northern Quebec. Part of KSB's mandate was to develop a secondary education program, a training program for Inuit teachers, an upgrading program for Qallunaat (defined as people who are not Inuit) teachers, and an adult education program (literacy classes, vocational training, etc.) in the North, in addition to encouraging and supervising post-secondary education for Arctic Quebec residents studying in the South (Vick-Westgate, 2002). While the agreements allowed for economic development and other formal endeavors, it also sparked a displacement of traditional roles of family onto services provided by the KRG, NRBHSS, and KSB.

Despite areas where rich cultural practices have persisted or have been adapted to modern life, rapid changes in the social structure, economy and culture of the region have also generated a high prevalence of social problems. Government-run social services have made efforts to address these social issues. However, according to the report by the Commission Des Droits De La Personne et Des Droits De La Jeunesse (2007), these services have failed to adapt to Inuit culture and realities. Today, according to the Commission's report, as the population surges with those aged 16 and under representing over one-third of the population, youth continue to be considered the worst victims of social ills. Duhaime's (2008) most recent statistical analysis of the region reports that teen pregnancy is three to four times higher in Nunavik than in the rest of Quebec, along with equally disproportionate teen suicide rates. Families as a unit also continue to suffer, with $40 \%$ more dependents re- 
lying on working people than in the rest of Quebec, while living amidst a burgeoning housing crisis, where $25 \%$ of single-family style dwellings are overcrowded with many in poor living conditions, more than anywhere else in the Canadian Arctic.

\section{Contextual Framework}

Colonization has played a central role in the development of Nunavik's social problems. In their critique of Canada's welfare state, Tester and Kulchyski (1994) document the implicit transmission of Southern values to Inuit during their relocation into settlements from 1939 to 1963 , setting the stage for the trauma of significant cultural and physical loss. The ensuing social problems in Nunavik can be seen as a reaction, a struggle to make sense of the unfamiliar (Drummond, 1997). Inuit communities face overwhelming challenges, and "southern" solutions have had little impact on the ongoing decades-long struggle with social problems in Nunavik (Ives \& Aitken, 2009). Problems are addressed by "tangled networks of interjurisdictional social welfare environments," (Baikie, 2009, p.51) contemporary manifestations of colonization which have not resulted in improved community wellbeing, as Duhaime's (2008) statistical review indicated.

Colonization has also influenced the ways in which workers, imported from Southern communities, interact with Inuit in various practice contexts. The financial, social, and cultural costs imposed by this importation of human capital are substantial (Coffey \& Tsosie, 2001). Southern workers often embody the cultural dissonance which is ever-present in modern Nunavik, presenting challenges of non-Inuit norms and laws against longstanding Inuit cultural codes. Even institutions set up to help the community, such as schools, were perceived as stripping Nunavimmiut of their choice and thus their identity, failing to meet real Inuit needs (Annahatak, 1994; Taylor, Crago \& McAlpine, 1993). Inuit who attended residential school in the past have often struggled with interactions with the presentday school community and have general feelings of distrust toward state-run educational institutions.

In this context, social work interventions must embrace a decolonizing approach that addresses colonization directly, its past injustices and its present manifestations. Grounded in social work practice with Indigenous populations, a decolonizing approach is one that seeks to liberate and heal, which necessitates a confirmation of Indigenous wisdom's place in the community (Briskman, 2008). Nunavik's educational crisis is intertwined with communities' social, economic and political exclusion and cultural marginalization. Overcoming this crisis can only happen with region-grounded interventions by people who know and understand the communities and who are able to understand and relate to Inuit ways of knowing, being and doing (Ives \& Aitken, 2009). The rejection of "contextfree knowledge" in favor of the "in-depth, rich understanding of the local, unique person, situation or community" (McKee, Delaney, \& Brownlee, 2009, p.193) is a central element in social work practice with Northern communities and one that supports the legitimacy of Indigenous knowledge. Moreover, a decolonizing approach requires reflection on privilege in relation to social location, recognizes the importance of Indigenous rights not only to Indigenous Peoples but also to non-Indigenous Peoples, and addresses issues of power that come with being a professional (Briskman, 2008). Recognizing the evolution of Inuit culture and its myriad expressions since European colonization, these initiatives must incorporate history (including that of colonization) as well as contemporary experience (Baikie, 2009). Those working with Inuit communities need a comprehensive, grounded understanding of Inuit in context: their histories and cultures and their political, economic, social, and health issues. Even if one were a member of a particular community, it would still be valuable to have a contextual understanding of that community, recognizing and working with multiple perspectives. Lacking this contextual knowledge could be ascribed to colonization, contemporary institutional structures and policies, and media, all creating barriers and nurturing cultural misconceptions and stereotyping for both Indigenous and non-Indigenous Peoples (Fenelon \& Hall, 2008; Gray, Yellow Bird, \& Coates, 2008). 
The success of decolonizing social work interventions in Nunavik depend on changes in the educational system. Meaningful, accessible, safe education is a core component of community wellbeing. Addressing the education crisis in Inuit communities facing social and economic struggles is imperative at a time when Nunavik is striving for regional government. Educational success remains elusive for disproportionately large numbers of Aboriginal students, which perpetuates social exclusion. This is particularly true in countries with colonial histories, such as Australia, Alaska, Hawaii, USA mainland, and Canada (Menzies \& Hingangaroa Smith, 2004). This is the reality in Nunavik's Inuit communities: approximately $50 \%$ of Nunavik's population does not complete high school (Duhaime, 2004). Continued high drop-out rates will further social exclusion of Nunavik's Inuit population and ensure that jobs requiring higher education qualifications, particularly leadership/managerial positions from which they could help to facilitate the embrace of a decolonizing perspective, continue to remain out of reach for a majority of the region's Inuit population. A report on social work in Nunavik with Inuit community service workers highlighted an eventual community goal of having social work positions filled by Inuit workers; however, they were concerned about the realities of this, given the drop-out rates and the limited numbers of people from Inuit communities attending University in any discipline (Thomson, Aitken, \& Ives, 2008). Decades of research have shown that engaging schools, parents, and communities in partnership improves educational outcomes (see Eccles \& Harold, 1996; Hill \& Taylor, 2004; Lamb-Parker, Piotrkowski, \& Peay, 1987). A significant aspect of this engagement involves negotiating the "culture of schooling" (Weaver, 2007). This negotiation can be more challenging for families from vulnerable populations, particularly for those in communities who, because of oppression, racism, and historical intergenerational trauma find it challenging to interact with the school community and have general feelings of distrust toward state-run educational institutions (Nekhwevha, 1999). Thus, in the Nunavik context, outcomes from effective social work and education initiatives are intertwined.

\section{Methods}

Given the exploratory nature of the study, a qualitative approach was adopted to gain knowledge of individuals' experiences and perceptions of their own communities' strengths and challenges. Qualitative methods allow a "return to the local—studied systems of knowledge, practices, and experiences in the context of those (local) traditions and ways of living which they are embedded, instead of assuming and attempting to test their universality" (Flick, 2006, p. 29). Researchers interviewed 52 respondents in five different communities of Nunavik, representing both large, government-centered communities as well as smaller villages which host different styles of living for Nunavimmiut.

Building on knowledge and contacts previously developed, the research team invited Inuit and non-Inuit members of Nunavik's key social and political institutions, including Makivik Corporation, Kativik Regional Government, and Kativik School Board, to participate on an Advisory Committee for the project. The Advisory Committee met with the research team periodically, once in person and the other times by phone or video conference. Collaboration with the Committee was one means of operationalizing principles within the study framework of Ownership of, Control over, Access to, and Power over data (OCAP) which guide Indigenous research in Canada. This committee played an integral role in advising the research team on project development, providing general cultural and political guidance, as well as identifying key informants selected from local community leaders.

Data Sources. The primary data source was an in-depth, individual interview guided by a semi-structured, open-ended interview schedule. The interviews, which were conducted by the research team (paper authors and one research assistant) explored perceptions of communal strengths and challenges, availability of social programs and resources, and regional governance development in Nunavik. Eleven questions solicited the subject's perception of 
three primary domains: major social problems in his/her community, communal capacity and assets for addressing social problems, and his/her knowledge of and experience with existing social welfare policies. However, if respondents chose to follow a different path, researchers respectfully followed respondents' shaping of the conversation to reflect their experiences and ideas. The interview schedule and project description was translated into Inuktitut. The majority of the interviews were conducted in English; nearly 30\% of the interviews were conducted in Inuktitut. Interpretation was provided by community research liaisons knowledgeable about the study and fluent in both English and Inuktitut. Ethical research guidelines, including confidentiality, were reviewed with liaisons. In addition to collecting first-person perspectives, interviews were used as a forum for asking community members about data and emerging interpretations in order to confirm or discount information and ideas (Lincoln \& Guba, 1985).

Interpretation and understanding of the interview data which were analyzed in this paper was also shaped by knowledge gained through two complementary activities in which the research team engaged: document review and sponsorship of community forums. Researchers conducted a review and analysis of historical, contextual, and statistical documents, including reports by the Commission des droits de la personne et des droits de la jeunesse, video sources, such as Martha of the North (2009), and statistical information.

In collaboration with the project Advisory Committee, the research team sponsored meetings on the Ungava Coast (Kuujjuaq, October 2010) and the Hudson Coast (Puvirnituq, February 2011). These public meetings brought residents together for further dialogue on existing social welfare policies and strategies for future programs and policies based on project data and themes. Some attendees were sponsored to attend the meetings from communities which the research team could not visit for data collection due to limited resources: Akulivik, Aupaluk, Kangiqsualujjuaq, Kangirsuk, Kuujjuaraapik, Quaqtaq, Salluit, Tasiujaq, and Umiujaq. Meeting participants represented a wide range of community and governmental organizations, including Makivik Corporation, Nunavik Board of Health and Social Services, Kativik School Board, Saputiit Youth Organization, Avataq Cultural Institute, Inuulitsivik Health Center, La Fédération des Coopératives du Nouveau-Québec, Youth Protection Services, as well as artists, elders, religious leaders, and others. Attendees participated in small-group discussions structured around data themes of culture, governance, family, and education, ending with a full-group strategy session on each theme, with the goal of producing ideas for future programs and policies. An interpreter was present for a two-way interpretation (English-Inuktitut). Discussions at the community meetings helped inform the recommendations offered at the close of this paper.

Interview Sample. The sample consisted of 52 Nunavimmiut (residents of Nunavik) living in the Nunavik communities of Inukjuak, Ivujivik, Kangiqsujuaq, Kuujjuaq and Puvirnituq. Participants were purposively chosen in partnership with the Advisory Committee. The research team compiled a list of directors/administrators of government and social service organizations in each community; these lists served as a tool for facilitating discussion with Advisory Committee members about potential interviewees. Advisory Committee members reviewed the lists, with the goal of identifying potential interviewees who were knowledgeable about social problems and communal assets in Nunavik and in their specific communities. They made many additions to the lists, identifying Nunavimmiut who were knowledgeable about community strengths/problems, but did not hold official leadership positions; they also made many substitutions, identifying alternate representatives of organizations on the lists as having exceptional community knowledge.

Direct recruitment of interview respondents by research team members was difficult. Challenges included overcoming discomfort with talking to Qallunaat strangers or with the idea of being researched, logistical problems in contacting people and finalizing interview arrangements from the south, and identification of participants who were willing to share their perspectives. For this reason, community liaisons, Inuit residing in the study commu- 
nities, were hired to help with recruitment of interviewees and coordination of interviews. The community liaisons were recruited by a research team member who lived and worked in Nunavik and who was familiar with multiple communities in the region. Community liaisons then recruited interviewees, initially working from the list constructed by the Advisory Committee and the identifying interviewees in harder to reach groups, including Elders, through the use of snowball sampling. Please see Figure 1 for distribution of respondents by community of residence and respondents' occupations.

\section{A Profile of CCDIN Respondents \\ Respondents by Community of Residence}

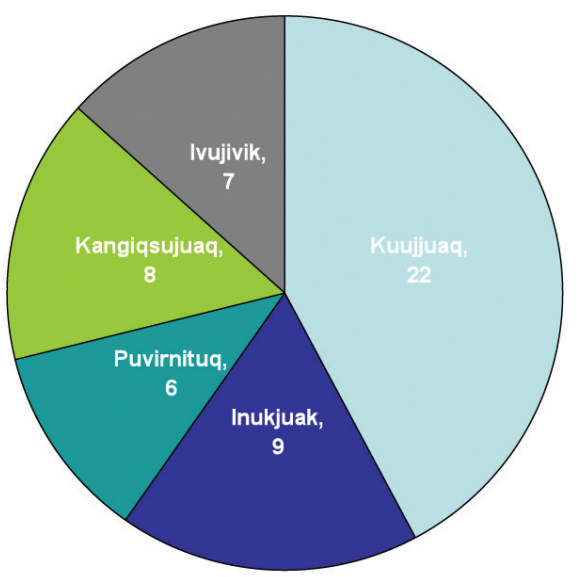

Respondents by Community of Residence

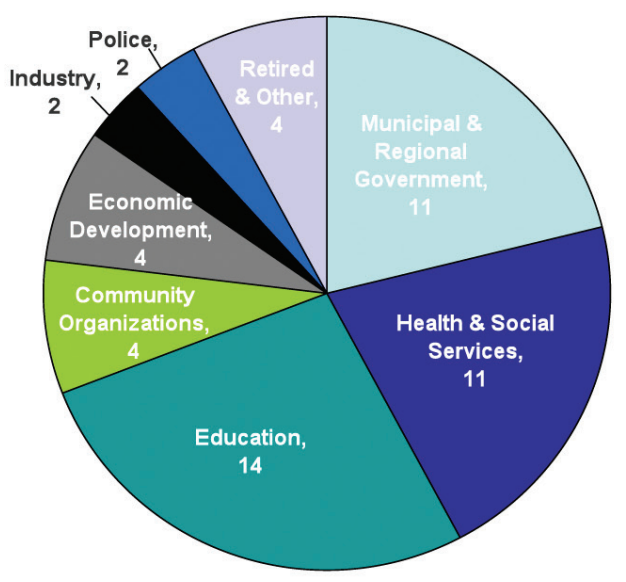

- 35 respondents were women, 17 were men.

- 16 respondents were between the ages of 20 and 35,16 aged $36-50,18$ aged 51-65, two respondents were older than 65 years.

Data Analysis. Researchers employed thematic content analysis to interpret the data. Interviews were transcribed verbatim and combined with the notes from the document review and community meetings. Open coding was used first, followed by more selective coding. For thematic analysis, coding consisted of breaking the text into small pieces and then interpreting it using frames developed from the data, an asset-based theoretical framework, and previous empirical research (Grbich, 2007). NVIVO qualitative data analysis software facilitated data analysis. Researchers co-coded transcripts and documents, discussing similarities and differences in their interpretations of the texts. These conversations produced categories that emerged from the data as well as those that related specifically to the study goals of exploring community strengths and challenges, availability of social programs and resources, and social capital. The data presented here focus on responses related to cultural aspects of participants' lives and their views on education. 
Study Limitations. Although 52 interviews were conducted in five communities, the sampling strategies employed limited the transferability of the findings to other contexts. However, as the purpose of the study was exploratory and the goal was to elicit perspectives on individuals' experiences of social issues in Nunavik, the methods were appropriate and could inform further study of this issue. It is also noted that the majority of interviews were conducted in English which, in most cases, was not the respondents' first language. It is probable that this shaped the way in which respondents expressed themselves. However, we provided an interview schedule in Inuktitut for respondents, and in cases where respondents were more comfortable speaking in Inuktitut, an interpreter was used. Interpreters were instructed to translate directly, minimizing their interpretation; however, it is likely that the interpreters' views and language choices affected both the interviewees' actual answers and researcher understanding of the answers they gave.

\section{Findings}

This section summarizes the major themes and findings from the interviews, focusing on key areas of culture and education. A strong trend among respondents was the indication of culture as a relevant social force in Nunavik. Many respondents saw the current educational system as problematic, but could also envision it as a vehicle for community renewal by incorporating mechanisms for greater traditional knowledge transmission. See Table 1 for a summary of major themes.

\begin{tabular}{|l|l|}
\hline \multicolumn{1}{|l|}{ Culture } & Importance of language preservation \\
\hline & Importance of transmitting knowledge of traditional practice \\
\hline & Difficulty of reconciling Qallunaat and Inuit cultures \\
\hline & Desire for recognition of cultural hybridity \\
\hline & Need for culturally appropriate programs and policies \\
\hline & $\begin{array}{l}\text { Importance of engaging Inuit in development of culturally appropriate pro- } \\
\text { grams/policies }\end{array}$ \\
\hline & Erosion of Inuit culture and resulting strain on cross generational ties \\
\hline & Need to bridge generational gaps \\
\hline & Importance of education \\
\hline & Social problems affect chances for educational success \\
\hline & Residential school trauma \\
\hline & Need for a culture of learning \\
\hline & Need for positive role models \\
\hline & Importance of focusing on youth \\
\hline & Need for education which furthers cultural preservation \\
\hline
\end{tabular}

Cultural preservation in the face of erosion. An overarching theme mentioned repeatedly across all five communities was the importance of preserving the Inuit culture. In this area, many respondents focused specifically on supporting the linguistic integrity of Inuktitut, the Inuit language. One respondent in Kangiqsujuaq stressed this, noting, "If we lose our language, we lose our life." Indeed, among the youth of Nunavik, most grow up learning two or three different languages. Inuktitut immersion is mandatory for Kindergarten through Grade 3. One non-Inuit respondent from the South, who had been living in Nunavik for a long time, made the following comment: 
This is such an intelligent group of people. How many kids do you know who, at age four, speak almost four, three languages? Here they almost all do. They speak Inuktitut at home, they speak English in the road, sort of English with their friends in the street, and French in school. The potential is there, I'm not sure that it's being tapped, and I'm not sure it's being encouraged (Inukjuak).

There was also a concern, however, for the pride that youth took in knowing and speaking Inuktitut. One respondent from Kangiqsujuaq worried about the largest community in Nunavik, Kuujjuaq, where he felt that "the young people are embarrassed about their language. They only speak Inuktitut at home."

Respondents also identified the transmission of knowledge about traditional practices such as hunting, fishing, and learning how to survive on the land as essential aspects of the cultural heritage and identity preservation of the Inuit. For example, respondents mentioned the Ungaluk Safer Communities Program as a positive program which gives youth the opportunity to learn about traditional knowledge and practices while building relationships with other youth. The program, designed as an alternative to building a detention center in Nunavik, has adopted culturally relevant approaches to address Nunavik's social issues. Traditional living practices were also seen by many respondents as an effective prevention strategy to keep youth busy and engaged with community role models. Respondents mentioned that many traditional practices and eating habits were still taught to youth today, not only as part of their heritage, but also because it is important for them to be able to survive on the land. As one elder respondent from Kangiqsujuaq emphasized: "(...) you should know how to build an igloo in the winter time if you are not able to go back home (...) So we like to teach the young ones how to build an igloo."

It was suggested that one of the ways forward for families and communities lay in finding constructive and creative ways of reconciling the Qallunaat and Inuit cultures, in order to help the youth develop a positive identity and outlook on their life and their unique "blended" culture. This is a challenge, however, in light of exposure to Qallunaat culture, through media particularly, and perspectives like that of one young Inuk woman in Kuujjuaq, who noted, "It's hard to be something that you're not, and that's what everyone wants to be-Qallunaat." Alongside the longing to have a Qallunaat life was the desire for recognition by younger respondents of their hybridity. One young woman from Puvirnituq, frustrated with what she felt was a lack of understanding by elders of those in her generation, cried, "I don't want to learn how to build an igloo!"

Today, Southern-structured institutions in Nunavik have become much more culturally sensitive and recognize the importance of preserving the Inuit language and culture. Still, learning to function and interact at the intersection of the two cultures can therefore be challenging. For example, making sure that Inuit were consulted at every step of program development in the North was one of the recurring themes among respondents. Echoing this respondent from Kuujjuaq, a majority of respondents felt that Southern programs implemented in the North could be more successful and effective if they were developed in collaboration with Inuit members of the community:

I think those programs should be designed in consultation with the Inuit people directly before they are put into place. (...) In our own language can we be explained that this is a program we're gonna offer, what do you think of it (...) consult the Inuit people first.

Many respondents mentioned creative and interesting strategies that various Nunavimmiut in different communities were developing in order to increase and promote ongoing cultural awareness in the provision of health care, education, job training and social services in Nunavik. Other respondents suggested interesting initiatives such as looking at traditional medicine and existing social networks to see how to better help the people who are suffering from illnesses such as depression. 
In tandem with their discussion of cultural preservation, respondents also pointed to elements of the cultural erosion of practices, lifestyles and values in the North. Growing contact with Southern lifestyles inevitably impacts the way Inuit live today. For centuries, Inuit have had to rely on themselves to survive in harsh living conditions. Although they celebrated the benefits of having increased access to health care, education, social services, and other "Southern" institutions, respondents also recognized that this had had a detrimental effect on their cultural traditions, such as strong social support systems. For example, a respondent from Ivujivik illustrated this by stating that "if the social services and government services were not present in the community, people would help each other more, like they used to."

In particular, respondents noticed an erosion of social ties between the younger and the older generations. Specifically, many respondents were concerned with the youth and their disconnect with elders. As one young respondent from Kangiqsujuaq remembered,

When I was growing up, I heard a lot of old people go on the radio and telling people this is bad, this is good. And when they did that, it was a lot calmer. But now they don't do that too often.

An elder from Kangiqsujuaq also felt a difference in the relationships between young people and elders. While she described the Hunters' Support Program, which provides food for a community freezer that people in need can access, she also touched on a pervasive sentiment among many participants across communities who saw young people struggling between an Inuit orientation for their lives and a Qallunaat orientation:

Yes, the Hunters Support [Program]. Everyone can use it. Older people use it, eating country food. Younger people are eating Qallunaat food...Y Younger people are not seeking help...they're being violent, and it's scary. A long time ago, it wasn't really there, the violence, but it's getting worse all the time. A long time ago, there was no alcohol, so it was very good. I seemed happy all the time.

One of the current challenges in the communities, therefore, is to build bridges between generations to help the youth rediscover the contribution that the older people can make to their lives because of their knowledge and experience of the past. In response to the many concerns respondents held for younger generations, the mention of elders as a guiding force was a common theme. A respondent in Puvirnituq highlighted this, saying "when elders say something very eye-opening, words, we have no choice but to listen to them." Elders were described also as an anchor for family values, defined as "someone who is wise, [...], [who has] experienced life the way it should be experienced. And one who knows how to raise a family, how to live productively within a community." Commenting on the 2007 Commission des droits de la personne et des droits de la jeunesse (Human Rights Commission) report on the state of Youth Protection Services in Nunavik, one respondent mentioned how important it was to reinstate a certain order in the community, and that this could be done by empowering and respecting the elders "because they were the ones guiding us in all areas of life" (Inukjuak).

Education. Continued high drop-out rates in Nunavik ensure that jobs requiring higher education remain out of reach for a majority of the community's Inuit, contributing to high unemployment levels. Individual Inuit community members who participate in traditional hunting, gathering and crafts may not need formal education in order to attain desired lifestyles; however, the collective health, well being and prosperity of Nunavimmiut is heavily dependent on increasing educational attainment in the region and this consideration may not be reaching the youth. One adult in Kuujjuaq touched on this saying, 
What I hear the kids saying is that well, I don't have to go to school because I am an Inuit, and I speak the language, and I will get any job. But it takes more than that to hold down a job. That is very important.

Addressing issues of social exclusion for Nunavik's Inuit depends largely on having an educated workforce, which has the expertise and knowledge to control and administer their own programs and services. Respondents suggested that rapid changes in Nunavik society and the resulting social issues had a direct impact on the children's and youth's well-being, and in particular, on their attendance and success in school. One respondent in Kuujjuaq framed it this way:

It [mental health problems] affect immediate family, the children, grandchildren, grandmothers, and also affect education as well. Because if the children are not nurtured lovingly, in their homes, or their homes are not well, mentally or socially, it affect their schooling.

Furthermore, issues such as overcrowded homes, family violence, and substance abuse can obviously be detrimental to a child's capacity to concentrate in school and to develop good study habits in the home, as another respondent described:

It's hard to get up in the morning when the house is filled with people. Maybe there's been a baby crying all night, maybe someone's been having a fight with someone all night, maybe someone's been arguing all night, maybe someone's been on a party all night. You get up in the morning, you might not have your own bed, you might just sleep where you can find a place, and there might not be any water for a shower. So it's not really conducive for good study habits, to stay in school. And it's certainly not conducive for good work habits.

Many respondents indicated another challenge to educational success: the history of trauma associated with a school environment. A respondent from Inukjuak commented on the residential school system and its lingering effects on parents:

Those kids that were put there [in the residential school] when they were six or seven (...), they lost their link to their parents, and now they are parents, and (...) there's a lot of times that they don't know how to show their love, and how to take care of their children. And those kids are having kids now, and I think we really have to address the issue about that.

Accordingly, respondents' suggestions for ways to increase educational achievement focused on needs and assets within the community at large, not just within the confines of Nunavik schools. For example, many respondents indicated that developing a culture of learning would be helpful in fostering a positive attitude towards education in all spheres of community life. One respondent in Kuujjuaq noted that

the parents are the ones who have to tell the kids: "it is important that you get an education, look at me, I cannot have a good job because I did not finish school and because of that look at where I am." So the parents have to be behind the kids, pushing them, telling them "I don't want you to be like me, I need you to be somebody... different, somebody who can stand on your own." 
Indeed, the need for parenting courses/coaching, the need for more positive role models in the lives of the children and youth, as well as more parental and community involvement in the education system were identified as ongoing priorities. A respondent from Ivujivik remarked on the important role of parents in education:

I explain about myself, because I never graduated. I would love to, but never... If you don't finish your high school, you will know nothing. You have to know everything if you want to be a pilot, or a nurse or a secretary. If you want to have a good job, you have to finish your high school. And that's the only way that you can finish your high school, if you are a good listener. If you don't understand, you have to ask your teacher, that's the only way you can learn.

The focus remained heavily on providing opportunity and direction for youth, as articulated by a respondent in Puvirnituq who said that, "I'm not concerned about anything else but where our young people are going from here." Still, a secondary challenge seemed to be creating opportunities for youth to succeed in their education without losing touch with Inuit culture-two forces which are constantly at odds with one another as Inuit and Qallunaat influences clash and converge in every area of modern life in Nunavik. One respondent from Kangiqsujuaq raised this issue specifically within the context of language:

From what I know, from kindergarten to grade three, they're speaking their own language. But when they go to grade four, they have to speak a different language that they don't know. The students will act up and will try to run away. And they will disturb other classes. [But] it starts to get better at the end of the year. It's the language issue.

Indeed, preservation and development of the Inuit language, culture and traditional lifestyle were mentioned as an important underlying value in current educational and community initiatives. Another respondent suggested programs which could offer cultural education as a facet of a child's education at large in Nunavik, or as an alternative for youth who have dropped out of school.

For those who wish to pursue post-secondary education, a considerable barrier to educational achievement is the lack of post-secondary educational opportunities in Nunavik. Currently, students who graduate from high school are counseled to attend either John Abbott College if they have chosen the English track in high school or Cegep Marie-Victorin if they have chosen the French track. Both schools, located in Montreal, require that students move away from their homes, communities, and thus, their support systems. There are opportunities for Secondary VI in Kuujjuaq and Kangiqsujuaq, but those programs are mainly for students who need an extra year of support before college. For those who manage to graduate from high school, the transition to college in the South is challenging. More than regional government, one respondent from Inukjuak felt that a priority in Nunavik was its own college:

I'm hoping that we're going to get a college before we get the regional government. Because we go up to high school here, Sec V, and then we have Adult Ed. But if we don't get a college in Nunavik, it's gonna be hard. I envy Iqaluit [Territory of Nunavut] because they have Arctic College there. I'm hoping that something like that will come up here. Because some of the kids, when they graduate, they go down to Montreal, and because they're not used to everything there...the time, and all the homework, all the transportation. They get overwhelmed and they just come back.

Since the creation of the Kativik School Board more than 30 years ago, the constant challenge has been to find creative ways to bridge different world visions and different ways of knowing, teaching and learning. Many of the recommendations of the Educational Task 
Force of the 1990s in Nunavik remain relevant for today, 20 years later. These included putting more effort into making the education system more culturally relevant for Nunavimmiut, focusing on education at all levels of development from early childhood through adulthood and ensuring that youth who graduate from high school in the North are on par with their fellow classmates from the South.

\section{Discussion}

The population of Nunavik has experienced, in the last few decades, numerous economic and social changes which have significantly altered their lifestyle. Today's Inuit must define their identity at the intersection of two cultures. The social and cultural environment of the present generation of Inuit is very different from the one in which their grandparents lived; the present generation cannot avoid considering the impact of Qallunaat cultural influences on the current Inuit way of life (Institut national de santé publique du Québec, 2008). However, despite these changes, respondents mentioned being confident that Inuit are "survivors" and want to protect their lifestyle, language and culture. During their interviews, most respondents focused on the many challenges faced by Inuit in Nunavik today, and identified multiple priorities: increasing educational attainment, facilitating access to appropriate, meaningful healing for multiple generations, strengthening connections between elders and youth and addressing the need for greater understanding on the part of Southern workers living and working in Nunavik. Finally, preservation and development of the Inuit language, culture and traditional lifestyle were mentioned as an underlying value which should be at the forefront of all future educational and community initiatives.

Studies have found a willingness on the part of Indigenous parents to be involved in their children's education but negative experiences in their own educational history (e.g., attending residential schools) and a pervasive distrust of the current educational system create serious barriers to their effective engagement (Fisher \& Campbell, 2002; RobinsonZanartu \& Majel-Dixon, 1996). In Nunavik's case, expectations of their children attending college where the curriculum is relevant for the North could increase the likelihood of parental support for higher education. One opportunity is Nunavut Arctic College in Iqaluit, Nunavut. As Nunavik is part of Inuit Nunaat (Inuit homeland) Nunavimmiut have family and other support networks which extend to Iqaluit. By remaining in the North, students may not face such a drastic change in culture and environment compared with a move to the South. A case study on post-secondary Inuit education concluded that key success factors for these students relied on the cultural competency of educators as well as an academic program designed to train Inuit students to work directly in their community, based on community needs (Silta Associates, 2007). Currently, Arctic College offers two degree programs (Bachelor of Education or Bachelor of Science in Nursing) through a collaboration with the University of Regina-Teacher Education and Dalhousie University for the Nunavut Nursing degree as well as vocational programs (Nunavut Arctic College, 2008).

In an effort to address the numerous challenges facing families in Nunavik, there has been an initiative by Inuit groups such as Pauktuutit to return to traditional healers and elders for advice on parenting in the modern world as well as conferences and retreats by the Kativik Regional Government dedicated to discussing the issue (Nunatsiaq News, 2009). There are a growing number of healing circles and individual and community-based initiatives aimed at reconstructing broken connections and reestablishing continuity in the transmission of traditional knowledge and values (Kirmayer, Simpson \& Cargo, 2003). Rediscovering one's culture and past traditions can in itself contribute to healing from historical traumas (Kirmayer, Simpson \& Cargo; Institut national de santé publique du Québec, 2008). Furthermore, healing through Inuit-specific values and remedies was identified as a priority of the Saturviit women's group in 2004 (Institut national de santé publique du Québec, 2008). Healing from past cultural trauma and loss is critical for moving forward and creating a healthy cultural environment to make knowledge transmission possible. Finally, reducing cultural isolation and enhancing cultural revitalization in the 
North may be achieved by facilitating Arctic-Inuit dialogue across communities and Circumpolar regions through such entities as the University of the Arctic. The University of the Arctic is a network of universities, colleges, and other organizations from the Arctic nations of Canada, Denmark/Greenland, Finland, Iceland, Norway, Russia, Sweden, and the USA, focused on higher education and research in the North (www.uarctic.org).

Respondents expressed concern for the growing cultural gap between youth and elders, and stressed a need to build intergenerational bridges in order to impart traditional knowledge in various ways, while still accepting certain changes, such as use of technology and English, the realities among youth. These "bridges" included cultural education for young people, land-based recreation, social education for struggling parents facing dependency and violence issues, and positive role-models for young people in the community. A common thread between these needs was the great need to bridge the growing generational gaps in areas of social climate, educational systems, language, land-based activity, and overall communication. Interviews echoed findings of statistical reports by Duhaime (2008), which reveal a rapidly growing youth who are influenced by a distinct cultural climate in the wake of modernization, and who maintain lifestyle indicators such as diet and language which are distinctly different from their predecessors.

\section{Recommendations}

The following recommendations are authors' recommendations based on study findings; they draw on the interview data analyzed in this paper and on the community forums which the research team sponsored in order to engage Nunavummiut in discussion of study findings. Recommendations focus on supporting education, healing programs, intergenerational land-based activities and designing Inuit-focused immersion programs for non-Inuit workers coming to Nunavik.

Supporting elementary and secondary education. The low academic retention rates in Nunavik call for increasing employment options for Inuit youth as well as restructuring the current system to allow for variance in education for those who prefer the pursuit of a job which requires on-site training or specific skill development. Alternative educational styles, including cultural, land-based education and technical education provide greater options to students who struggle linguistically or academically in certain areas, and could prevent early dropout and the subsequent social consequences, such as early pregnancy and drug and alcohol abuse (Duhaime, 2008). Additionally, facilitating provincial-territorial cooperation between Quebec and Nunavut could allow choice for Nunavik's youth who want post-secondary education at an institution that has designed curricula to respond to the North's specific needs, integrally involves Elders in college life, and facilitates an Inuit language- and culture-centered learning environment (Nunavut Arctic College, n.d.).

Focusing on engaging parents and families in schools can be a way to alleviate persistent challenges within the education system whereby mostly Southern teachers employ a Southern educational model for a new generation of Inuit whose families are unaccustomed to, or have even been traumatized, by formal education. Finding areas of education to include family and community members to work alongside teachers would provide an opportunity to mutual collaboration, facilitating mutual respect and understanding of both Southern and Northern styles of learning. Such parent/family engagement would also provide a vehicle for positive opportunities for parents/family members to support their children in their completion of elementary and secondary education.

Supporting healing programs. Traditional wellness and healing was seen to be a notable source of strength for community members struggling with social challenges of drug abuse, domestic violence, mental health, or other social issues. This work, disseminated through wellness workers and other healing, has been limited due to insufficient support of these positions in multiple villages throughout Nunavik. Still, projects conducted by wellness 
workers are seen by the community as highly valued and effective in dealing with the trauma of history and current social challenges. Many, especially elders, may find the techniques employed by traditional healers as more approachable and culturally familiar, while acting as a form of cultural preservation and knowledge transmission for younger generations. Greater funding is required to ensure consistent programming by wellness workers across all 14 Nunavik communities.

Supporting Inuit-designed cultural immersion for non-Inuit social workers and teachers. What has brought the non-Inuit social worker or teacher to Nunavik? In what ways does the social worker or teacher's past and present shape his or her desire to work with Inuit in Nunavik? A learning experience, such as cultural immersion, designed by Inuit and centered on Inuit ways of knowing, learning, and being could reflect "Indigenous forms of practice, that is, to provide professional services in a manner that is effective and consistent with local cultures and contexts - local knowledge, local traditions and local practices" (Gray, Coates, \& Yellow Bird, 2008, p. 6). Such an experience, adapted for workers already in the field or new to a community could enable workers to learn firsthand from community members through presentations, interactive workshops, cultural activities and ceremonies. It is critical to capitalize on the community's capacity and, at the same time, increase workers' awareness of the capacity that already exists in the community (Ives \& Loft, in press).

Self reflection, essential for moving away from ethnocentrism and towards a clearer understanding regarding a worker's motivation in working with Indigenous Peoples, should be linked to a learning experience that purposefully addresses Eurocentric perspectives that have shaped social work and education programs. Self reflection allows for a clearer understanding of a worker's motivation in working with Indigenous Peoples. In social work, students enter their educational programs with enthusiasm, as well as idealism (Wehbi, 2009), altruism (Rotabi, Gammonley \& Gamble, 2006), and naïveté. Wehbi discussed the deconstruction of students' motivations for international social work, similar to reasons that non-Indigenous students give for wanting to work with Indigenous Peoples. In the context of international social work practice, Wehbi cautioned that social work students may be motivated by (a) fascination with other cultures, (b) liking people of another country, (c) making a difference, and (d) giving something back. Those who intend to work in Nunavik should process their own motivations for wanting to work with Inuit to address possible attitudes of "cultural imperialism and voyeurism" (Wehbi, p. 52).

Supporting outdoor, land-based activities. Outdoor, land-based activities were cited across education and culture themes as a key target for strengthening youth's connections to Inuit traditions as well as with elders. Specific activities included camping, berry-picking, boating, hunting, and carving. While these activities were seen as overlooked by the current educational system, they were seen by community members as having a legitimate place in schools as a form of cultural knowledge transmission and bridging of educational styles between North and South. Similarly, as the widening gap between generations was a strong concern, land-based activities were thought to represent a possible common interest among youth, parents, and grandparents. Whereas generational differences between these groups often hinder family bonding activities, land-based activities have seen to be successful as a cohesive family undertaking, and has the potential to provide a platform for healthy family support and communication.

\section{Conclusion}

The importance of Indigenous knowledge from elders and community leaders as an integral pedagogical component of education is present in other Indigenous communities. In a study conducted in a Yup'ik community in Alaska, elders were still called upon to impart cultural wisdom to younger generations, and teachers in formal school settings were also involved in facilitating cultural and land-based education into the standardized American 
curriculum (Hense \& Vanett, 1993). Greenlandic schools have taught special subjects such as hunting, fishing, and skin-sewing, alongside state compulsory topics like math and science (Goldbach \& Winther-Jensen, 1988). One of the key challenges, however, in carrying out a dualistic education system continues to be the scarcity of culturally appropriate educators who are also qualified to teach in state-run educational institutions. In Greenland, even after a decade of officially attempting to integrate Inuit cultural contexts into formal education structures, one third of lessons in Folkeskole (primary and lower secondary levels) were taught by teachers who do not speak Greenlandic, while another third were taught by teachers with insufficient education by state standards (Goldbach \& Winther-Jensen, 1988).

Social work with Indigenous peoples has much to teach other disciplines. Social work's efforts to center context in social work practice with Indigenous Peoples can inform education in Nunavik to make schools a place where students see themselves and their cultural contexts as relevant and their communities' cultural knowledge as valorized. As a contextual, holistic discipline, social work is in a unique place to collaborate in order to unravel the "tangled networks" referred to above by bringing together multiple community stakeholders representing various community entities to make "each part of the community... an integral part of the whole flowing movement...modeled on the inward wholeness and harmony (Ermine, 1995, p.105).

\section{References}

- Annahatak, B. (1994). Quality education for Inuit today? Cultural strengths, new things, and working out the unknowns: A story by an Inuk. Peabody Journal of Education, 69, 2, 12-18.

- Archibald, L., \& Grey, R. (2000). Evaluating models of healthcare delivery in Inuit regions. Inuit Tapiriit Kanatami, Ottawa.

- Baikie, G. (2009). Indigenous-centred social work: Theorizing a social work way of being. In R. Sinclair, M. A. Hart, and G. Bruyere (Eds.), Wichihitowin: Aboriginal social work in Canada (pp. 42-61). Halifax, NS: Fernwood.

- Briskman, L. (2008). Decolonizing social work in Australia: Prospect or illusion? In M. Gray, J. Coates, and M. Yellow Bird (Eds.), Indigenous social work around the world: Towards culturally relevant education and practice (pp. 83-93). Surrey, England: Ashgate.

- Chabot, M. (2003). Economic changes, household strategies, and social relations of contemporary Nunavik Inuit. Scott Polar Research Institute, University of Cambridge. http://journals.cambridge.org/action/displayFulltext?type=1\&fid=139502\&jid=POL\&volume Id=39\&issueld=01\&aid=139501

- Coffey, W., \& Tsosie, R. (2001). "Rethinking the Tribal Sovereignty Doctrine: Cultural sovereignty and the collective future of Indian nations," Stanford Law \& Policy Review, 12, 191-202.

- Collings, P. (2000). Aging and life course development in an Inuit community. Arctic Anthropology, 37, 111-125. University of Wisconsin Press. http://www.jstor.org/stable/ pdfplus/40316533.pdf

- Commission des droits de la personne et des droits de la jeunesse (2006). Nunavik: Report, Conclusions on the Investigation and Recommendations.

- Drummond, S. G. (1997). Incorporating the familiar: An investigation into legal sensibilities in Nunavik. Montreal, QC: McGill-Queen's University Press.

- Duhaime, G. (2008). Socio-economic profile: Nunavik. Nunivaat Arctic Statistics. Retrieved on September 24th, 2010 from http://www.nunivaat.org/TableViewer. aspx?U=http://www.chaireconditionautochtone.fss.ulaval.ca/extranet/doc/159.pdf

- Duhaime, G. (2007). Profil socioéconomique du Nunavik 2006. Quebec, Chaire de recherche du Canada sur la condition autochtone comparée, Université Laval.

- Duhaime, G. (2004). Social and economic situation of Nunavik and the future of the state. Nunivaat, Nunavik Statistics Program. Available at: www.nunivaat.org 
- Eccles, J., \& Harold, R. (1996). Family involvement in children's and adolescents' schooling. In A. Booth and J. Dunn (Eds.), Family-school links: how do they affect educational outcomes? (pp. 3-34). Mahwah, NJ: Lawrence Erlbaum and Associates.

- Ermine, W. (1995). Aboriginal epistemology. In M. Battiste and J. Barman (Eds.), First Nations education in Canada: The circle unfolds. Vancouver, BC: UBC Press.

- Fenelon, J. V., \& Hall, T. D. (2008). Revitalization and Indigenous resistance to globalization and neoliberalism. American Behavioral Scientist, 51, 1867-1901.

- Fisher, J., \& Campbell, L. (2002). Improving the Aboriginal educational experience in public schools. Alberta: Peace Wapiti School Board.

- Goldback, I., \& Winther-Jensen, T. (1988). Greenland: Society and education. Comparative Education, 24, 2, 257-266.

- Gray, M., Yellow Bird, M., \& Coates, J. (2008). Towards an understanding of Indigenous social work, in M. Gray, J. Coates, \& M. Yellow Bird (eds.), Indigenous social work around the world: Towards culturally relevant education and practice (pp. 49-58). Hampshire, England: Ashgate.

- Grbich, C. (2007). Qualitative data analysis. Los Angeles, CA: Sage.

- Hense, R. C., \& Vanett, L. (1993). To walk in two worlds: Or more? Challenging a common metaphor of Native education. Anthropology and Education Quarterly, 24, 2, 116-134.

- Hill, N. E., \& Taylor, L.C. (2004). Parental school involvement and children's academic achievement; pragmatics and issues. Current Directions in Psychological Science, 13, 4, 161-164.

- Institut national de santé publique du Québec (2008). Nunavik: The place where we live. Développement social, 9, 1, 8-28.

- Inuit Tapriit Kanatami (2007). Post-Secondary Case Studies in Inuit Education. Discussion Paper No. 2 for the Naional Inuit Education Summit. Silta Associates.

Retrieved on July 26, 2011 from http://www.itk.ca/sites/default/files/Post-SecondaryCase-Studies-in-Inuit-Education 0.pdf

- Ives, N., \& Aitken, O. (2009). From colonized region to globalized region? Challenges to addressing social issues in Nunavik in the transition to regional government. Indigenous Policy Journal, 20, 3. http://ipjournal.wordpress.com/2009/12/16/from-colonizedregion-to-globalized-region/

- Ives, N., Aitken, O., Loft, M., \& Phillips, M. (2007). Rethinking social work education for Indigenous students: Creating space for multiple ways for multiple ways of knowing and learning. First Peoples Child \& Family Review, 3, 4, 13-20.

- Kativik School Board; n.d. History of Kativik School Board. Kativik School Board Website. Retrieved on May 27th, 2011 from http://www.kativik.qc.ca/about-kativik-school-board

- Kirmayer, L., Simpson, C., \& Cargo, M. (2003). Healing traditions: Culture, community and mental health promotion with Canadian Aboriginal peoples. Australasian Psychiatry, 11, S15-S23.

- Lamb-Parker, F., Piotrkowski, C. S., \& Peay, L. (1987). Head Start as a social support for mothers: the psychological benefits of involvement. American Journal of Orthopsychiatry, 57, 2, 220-33.

- Lincoln, Y. S., \& Guba, E. G. (1985). Naturalistic Inquiry. Beverly Hills, CA: Sage.

- McGrath, M. (2006). The long exile: A tale of Inuit betrayal and survival in the High Arctic. New York: Vintage.

- McKee, M. Delaney, R., \& Brownlee, K. (2009). Reflective practice: The key to contextsensitive practice in Northern communities. In R. Delaney and K. Brownlee (Eds.), Northern and rural social work practice: A Canadian perspective (pp.192-208). Thunder Bay, Ontario: Centre for Northern Studies.

- McShane, K., Hastings, P. D., Smylie, J. K., Prince, C., \& Tungasuvvingat Inuit Family Resource Center. (2009). Examining evidence for autonomy and relatedness in urban Inuit parenting. Culture \& Psychology, 15, 4, 411-431. http://cap.sagepub.com/cgi/ reprint/15/4/411. 
- Menzies, C. R., \& Hingangaroa Smith, G. (2004). Editorial: Transformational sites of Indigenous education. Canadian Journal of Native Education, 28, 1-7.

- Nekhwevha, F. (1999). No matter how long the night, the day is sure to come: Culture and educational transformation in post-colonial Namibia and post-apartheid South Africa. International Review of Education, 45, 491-506.

- Nunavut Arctic College (2008). Nunavik Arctic College Website: Customized Training. Retrieved on July 26th, 2011 from http://www.arcticcollege.ca/about/customizedtraining eng.aspx

- Nunavut Arctic College (n.d.). Nunavik Arctic College Website: Teaching and learning principles. Available at: http://www.arcticcollege.ca/publications/posters/3265-006\%20 TL\%20Poster Eng Inuk.pdf

- Pauktuutit Inuit Women of Canada (2006). National Inuit strategy for abuse prevention. Retrieved on October 10, 2010 from http://www.pauktuutit.ca/pdf/publications/abuse/ InuitStrategy_e.pdf

- Penny, C. (2009). Formal educational attainment of Inuit in Canada, 1981-2006. In J. P. White, J. Peters, D. Beavon, \& N. Spence (eds.), Aboriginal education: Current crisis and future alternatives (pp. 33-46). Toronto: Thompson Educational.

- Popay, J., Enoch, E., Johnson, H., \& Rispel, L. (2006). Social Exclusion Knowledge Network: Scoping of SEKN and proposed approach. Lancaster University, UK: Institute for Health Research. Available at: http://www.who.int/social determinants/resources/ sekn_scoping.pdf

- Robinson-Zanartu, C., \& Majel-Dixon, J. (1996). Parent voices: American Indian relationships with schools. Journal of American Indian Education, 36 (Fall), 33-54.

- Rodon, T., \& Grey, M. (2009). The long and winding road to self-government: The Nunavik and Nunatsiavut experiences. In F. Abele, T.J. Couchene, F.L. Seidle, \& F. St-Hilaire (Eds.), The Art of the State IV: Northern Exposure; Peoples, Powers and Prospects in Canada's North (pp.317-343). Montreal, QC: Institute for Research on Public Policy.

- Rotabi, K. S., Gammonley, D., \& Gamble, D. N. (2006). Ethical guidelines for study abroad: Can we transform ugly Americans into engaged global citizens? British Journal of Social Work, 36, 451-465.

- Statistics Canada (2006). Educational Portrait of Canada: Aboriginal Population. 2006 Census of Canada Analysis Series. Retrieved April 7, 2011 from Statistics Canada, http://www12.statcan.ca/census-recensement/2006/as-sa/97-560/p17-eng.cfm

- Taylor, D. M., Crago, M. B., \& McAlpine, L. (1993). Education in Aboriginal communities: Dilemmas around empowerment. Canadian Journal of Native Education, 20, 176-183.

- Tester, F. J., \& Kulchyski, P. (1994). Tammarniit (mistakes): Inuit relocation in the Eastern Arctic, 1939-63. Vancouver, BC: UBC Press.

- Thomson, W., Aitken, O., \& Ives, N. (2008). Final report of the Rethinking social work education in First Nations and Inuit communities project, funded by Ministère de I'Education, du Loisir et du Sport de Quebec.

- Vick-Westgate, A. (2002). Nunavik: Inuit controlled education in Arctic Quebec. Calgary: University of Calgary Press.

- Weaver, S. M. (2007). Cultivating connections with parents. The Clearing House, 81, 5-7.

- Wehbi, S. (2009). Deconstructing motivations: Challenging international social work placements. International Social Work, 52, 48-59.

- Wilson, G.N. (2008). Nested federalism in Arctic Quebec: A comparative perspective. Canadian Journal of Political Science 41 (1), 71-92. 